\title{
AC 2012-3887: ENGINEERING STUDENTS' VIEWS OF THE ROLE OF ENGINEERING IN SOCIETY
}

\section{Nathan E. Canney, University of Colorado, Boulder}

Nathan Canney received bachelor's degrees from Seattle University in civil engineering and applied mathematics. After graduation, he worked for Magnusson Klemencic Associates in Seattle, Wash., as a structural engineer on high-rise residential buildings. Canney returned to school at Stanford University for a master's degree and is currently pursuing a doctoral degree at the University of Colorado, Boulder, in civil engineering, with an engineering education research focus.

\section{Dr. Angela R. Bielefeldt, University of Colorado, Boulder}

Angela Bielefeldt has been a professor in the Department of Civil, Environmental, \& Architectural Engineering at the University of Colorado, Boulder, since 1996. She has taught first-year introductory courses, senior capstone design, and specialty senior-level/graduate courses in environmental engineering. Her research interests in engineering education have focused on service learning, sustainability, and ethics. 


\title{
Engineering Students' Views of the Role of Engineering in Society
}

\begin{abstract}
A developed sense of social responsibility should be inherent in the engineering profession such that any project can be seen as service to a community. Academic institutions carry the responsibility of teaching engineering students not only technical skills but also professional skills that relate to social responsibility, such as an understanding of professional and ethical responsibility and of the global and societal impacts of engineering decisions. Teaching techniques such as project-based service learning (PBSL) could increase a student's awareness of social responsibility due to the community engagement (typically with underserved populations) and the reflective aspect inherent in PBSL. This study presents pre-post data from an assessment of engineering students' development of social responsibility. The classes targeted for this study include freshman introductory classes, a sophomore/junior environmental engineering fundamentals class, civil engineering senior capstone design and graduate level structures and community development classes. In general, little change was seen in the pre- and post- results from a single semester. There were, however, notable differences between the graduate community development course and other courses, and between PBSL/PBL courses and traditional courses.
\end{abstract}

\section{Introduction}

The global and societal problems that engineers face are complex, requiring a broad range of professional and technical skills. The burden to prepare these future engineers falls mainly upon academic institutions. The Engineering Accreditation Commission of ABET establishes standards for accrediting engineering programs. ABET requires that graduates from accredited programs possess, among other skills, an understanding of professional and ethical responsibilities (3.f), and understand the impact of engineering solutions in a global and societal context (3.h) ${ }^{1}$. A well-developed sense of social responsibility, contextualized within the engineering profession, embodies both of these professional skills.

Social responsibility can be defined as "acting with concern and sensitivity, aware of the impact of your actions on others, particularly the disadvantaged"2. In the context of engineering, a welldeveloped sense of social responsibility would manifest itself through sustainable design, community involvement in the design process, life-cycle considerations, work in developing communities, and in many other ways. In the end, an engineer with strong beliefs of social responsibility would see their work, be it DOT bridges or water treatment facilities in developing communities, as a service to society through the ways in which they engage with the community and give full considerations to the impacts of their work.

Different teaching methods may have varying effects on the development of social responsibility in students. Previous studies have addressed broadly the development of ABET professional skills through service ${ }^{3,4}$. Learning Through Service (LTS) is a pedagogical tool that is believed to expose students to ideas of social responsibility. LTS is an umbrella term that encompasses Service-Learning (SL), which is curricular and directly related to course learning objectives, and 
also extracurricular LTS such as Engineers without Borders (EWB). LTS is "a form of active learning where students work on projects that benefit a real community or client while also providing a rich learning experience" $"$. The reflection inherent in LTS helps students to understand the role of engineering in the context of larger social issues ${ }^{6}$. Many studies have been conducted showing the benefits of LTS on students' academic, personal and professional advancement $^{7,8}$. Non-engineering studies have found that incorporating SL into courses in any discipline helps "students develop a heightened sense of civic responsibility and personal effectiveness".

The rise of engineering organizations that focus on development work could be a sign that the current generation has a stronger sense of social responsibility and its connection with engineering than in the past. EWB, Purdue's Engineering Projects in Community Service (EPICS) program, and the University of Colorado Boulder's Mortenson Center in Engineering for Developing Communities are just a few and their numbers seem to be growing. There is undoubtedly a cyclical relationship in these programs where students with some level of social responsibility are drawn to participate, but, additionally, their engagement in these programs presumably increases their awareness and deepens their sense of social responsibility. Other forms of LTS may also provide this cyclical deepening of beliefs of social responsibility once a student is engaged in the activities.

Finally, a greater focus on the development of social responsibility may provide greater attraction and retention of female and underrepresented minority students to engineering. Previous studies have indicated that female students tend to be over-represented in engineering service activities (such as EWB \& EPICS) ${ }^{4}$ and that service seems to be more important to underrepresented minorities than other groups ${ }^{10}$.

This study provides the first iteration results using the Engineering Professional Responsibility Assessment (EPRA) tool. This survey was distributed to different courses in order to sample students from different academic ranks, majors, and in courses using a variety of teaching methodologies. Variations in student responses based upon these factors are examined in this study, directed by the following research questions.

\section{Research Questions}

The specific research questions being explored in this study are:

1. Are there differences among the attitudes of incoming engineering students who have identified different majors of primary interest?

2. Do the social responsibility attitudes of students change from the beginning to the end of the semester in courses where the content targets ABET outcomes F and H?

3. Do the learning activities of the students (traditional vs. PBL vs. PBSL) impact changes in social responsibility over the course of a semester?

4. Does social responsibility tend to change over time through a civil engineering curricula? 


\section{Methods}

\section{Pilot Study Assessment Instrument}

For this study, the results from an assessment of engineering students using the Engineering Professional Responsibility Assessment (EPRA) tool are examined. EPRA is rooted in the Professional Social Responsibility Development Model $^{11}$ which is a moral development model that describes 12 developmental stages of personal and professional social responsibility. The twelve constructs of the EPRA tool are summarized in Table 1. The Professional Social Responsibility Development Model is based on three existing models: Schwartz's altruistic behavior development model ${ }^{12,13}$, Ramsey's model for incorporating social parameters into the scientific process ${ }^{14}$, and Delve et al.'s service learning model ${ }^{15}$. The reliability and validity of the EPRA tool are in the process of being determined and preliminary results show strong internal consistency and construct validity ${ }^{11}$.

Table 1. EPRA Tool Construct Descriptions

\begin{tabular}{|l|l|}
\hline Construct & Description \\
\hline 1. Awareness & An awareness that others are in need \\
\hline 2. Ability & A recognition of one's ability to do something to help those who are in need \\
\hline 3. Connectedness & A feeling of moral obligation to become involved in social issues \\
\hline $\begin{array}{l}\text { 4. Base } \\
\text { Knowledge }\end{array}$ & The base technical knowledge of a given profession are acquired \\
\hline 5. Analyze & $\begin{array}{l}\text { An ability to analyze social issues from a professional perspective and to } \\
\text { identify the key players and how their beliefs/ideals influence the issue }\end{array}$ \\
\hline $\begin{array}{l}\text { 6. Professional } \\
\text { Ability }\end{array}$ & $\begin{array}{l}\text { A recognition that one's professional skills have the ability to do something } \\
\text { to help those who are in need }\end{array}$ \\
\hline $\begin{array}{l}\text { 7. Professional } \\
\text { Connectedness }\end{array}$ & $\begin{array}{l}\text { A feeling of moral obligation to become involved in social issues because of } \\
\text { one's professional abilities }\end{array}$ \\
\hline $\begin{array}{l}\text { 8. Costs/Benefits } \\
\text { Assessing the costs and benefits of personal participation and also of the } \\
\text { proposed solution, drawing upon professional expertise }\end{array}$ \\
\hline 9. Action & Engaging in actions such as volunteering, mentoring, etc. \\
\hline 10. Realization & A connection between social issues and personal life is developing \\
\hline 11. Activation & $\begin{array}{l}\text { One begins to grasp a larger, more complex understanding of social issues } \\
\text { and often becomes an advocate for a particular group }\end{array}$ \\
\hline $\begin{array}{l}\text { 12. } \\
\text { Internalization }\end{array}$ & $\begin{array}{l}\text { The participant is fully engaged in their service experiences, often causing } \\
\text { their ideals to influence personal or professional goals }\end{array}$ \\
\hline
\end{tabular}

A pilot study was conducted to assess the development of social responsibility of engineering students at a large, public institution using the first draft of the ERPA tool. The EPRA tool employs mixed methods and consists of 65, 7-point Likert-style questions, two short-answer questions, a multiple-selection list of motivations for community service, questions about volunteer activities, and demographic questions including gender, academic rank and major. Eleven of the twelve underlying constructs of the EPRA tool from the Professional Social Responsibility Development Model are addressed by the Likert-style questions (See Canney and 
Bielefeldt ${ }^{11}$ for survey constructs and correlated survey questions). Many of these questions were compiled from previously validated surveys, such as the CSAS ${ }^{16}$, Pittsburgh Freshman Engineering Attitudes Survey (PFEAS) ${ }^{17}$, and Academic Pathways of People Learning Engineering Survey (APPLES) ${ }^{18}$. The other construct, Action, is assessed primarily by the volunteer frequency questions, but also had two Likert-questions associated with it. For the postsurvey, additional questions were asked specifically about the influence of the class being assessed on the ethical beliefs and ideals of social responsibility. In both surveys, negatively worded questions were used, but scores were reversed in determining construct averages. Both the pre- and post- survey had IRB approval and survey included informed consent forms. Student names were coded and separated from survey responses per IRB protocol.

\section{Pilot Study Courses}

The following classes were chosen as samples of varied teaching methods and academic rank to be assessed for the pilot study. Table 2 provides a summary of the courses chosen including relevant learning objectives and teaching methods. More detailed descriptions of each course are provided below.

Table 2. Summary of Pilot Study Courses

\begin{tabular}{|l|l|l|l|l|}
\hline Course & $\begin{array}{l}\text { Student } \\
\text { Rank }\end{array}$ & $\begin{array}{l}\text { Student } \\
\text { Engineering Majors }\end{array}$ & $\begin{array}{l}\text { ABET F or H as } \\
\text { Learning Objective }\end{array}$ & $\begin{array}{l}\text { Teaching } \\
\text { Method }\end{array}$ \\
\hline $\begin{array}{l}\text { GEEN 1400 } \\
\text { (Engr. Projects) }\end{array}$ & First-year & any & PBSL \\
\hline $\begin{array}{l}\text { EVEN 1000 } \\
\text { Intro to EVEN) }\end{array}$ & First-year & EVEN & F & Traditional \\
\hline $\begin{array}{l}\text { CVEN 1317 } \\
\text { (Intro to CVEN) }\end{array}$ & First-year & CVEN & Fustainability & Traditional \\
\hline $\begin{array}{l}\text { CVEN 3414 } \\
\text { (Fund. EVEN) }\end{array}$ & $\begin{array}{l}\text { Sophomore } \\
\text { Junior }\end{array}$ & $\begin{array}{l}\text { EVEN } \\
\text { CVEN }\end{array}$ & H & Traditional \\
\hline $\begin{array}{l}\text { CVEN 4899 CVEN } \\
\text { Sr. Design) }\end{array}$ & Senior & CVEN & F, H & PBL \\
\hline $\begin{array}{l}\text { CVEN 5525 } \\
\text { (Framed Structures) }\end{array}$ & $\begin{array}{l}\text { Graduate/S } \\
\text { enior }\end{array}$ & CVEN & [control] & Traditional \\
\hline CVEN 5919 (SCD I) & Graduate & CVEN & H & PBSL \\
\hline
\end{tabular}

* Bold designates that the ABET outcome is a central learning objective for that course

\section{EVEN 1000 Introduction to Environmental Engineering (Intro to EVEN)}

Introduction to Environmental Engineering is a 1-credit course required for all environmental engineering majors. It is scheduled to be taken in the first semester. The ability to evaluate ethical problems based upon academic honor codes, environmental ethics and professional codes of ethics for engineers is one of the stated learning objectives for the course. Additionally, students are exposed to socioeconomic challenges in the environmental engineering field and issues of sustainability and life cycle assessment. The course included lectures, guest lectures, and projects to enhance students' understanding of environmental engineering. 
GEEN 1400 Engineering Projects (Engr. Projects)

The first year projects course is a 3 -credit course required for about half of the engineering majors at the University. Students take the course in either their first or second semester. The course is "an interdisciplinary hands-on design/build/test course. Through this course, students put engineering theory into practice early in their undergraduate years by working in teams to design, build and test new products and inventions"19. In fall 2011, one of the sections of the course focused projects on altruistic engineering and design for local community clients.

\section{CVEN 1317 Introduction to Civil Engineering (Intro to CVEN)}

Introduction to Civil Engineering is a 1-credit course required for all civil engineering majors. It is scheduled to be taken in the first semester. Among the stated learning objectives for the course are: apply the professional codes of engineering ethics to evaluate situations you may encounter in your career" and "define sustainability, describe its importance to engineering, and identify aspects of sustainability in civil engineering projects." Because sustainability includes the social pillar, this learning unit includes discussion of the impacts of engineering in a societal context. There are homework assignments associated with both the ethics and sustainability learning goals. Both of these assignments included case studies. For their semester term papers, students are required to discuss non-technical and societal issues associated with a civil engineering project (i.e. the Minneapolis bridge collapse, the Three Gorges Dam). In-class the predominant teaching style is lecture-based. Students taking this course in their first semester also are typically enrolled in Calculus 1, Chemistry for Engineers, First-Year Engineering Projects, and a humanities or social science elective.

\section{CVEN 3414 Fundamentals of Environmental Engineering (Fund. EVEN)}

The Fundamentals of Environmental Engineering course is a 3-credit course required for all civil engineering and environmental engineering majors. The course emphasizes chemical, ecological, and hydrological fundamentals and the importance of mass and energy balances in solving environmental engineering problems related to water quality, water and wastewater treatment, air pollution, solid and hazardous waste management, sustainability, and risk assessment. One of the three stated learning objectives for the course is that students understand the role of environmental engineering in our society. However, instructors indicated that ABET outcomes $\mathrm{F}$ and $\mathrm{H}$ were only emphasized to a small degree in the course. The primary instruction method used in the course is lecture-based with a large number of homework assignments and some exams. Environmental engineering (EVEN) majors typically take the course in their third or fourth semester. In the fall semester, these EVEN students would also normally be enrolled in Calculus 3, Physics 2, and Solid Mechanics or a humanities/social science elective. The civil engineering majors typically take the course in their $5^{\text {th }}$ semester, along with Introduction to Construction, Hydraulic Engineering, Structural Analysis, and Geotechnical Engineering 1.

\section{CVEN 4899 Civil Engineering Senior Design Project (Sr. Design)}

The CVEN 4899 course is the required 4-credit capstone design course for all civil engineering majors. The course is only offered in fall semester. The course provides a simulated real world design and construction planning experience with multiple constraints including budget, schedule, technical, regulatory, and societal. Teams of 4 to six students encompass the multiple civil engineering sub-disciplines. In fall 2011 multiple student teams competed on two separate 
design projects; the municipal client selected the winning team on each project at the end of the semester. The primary learning method in the course is the student-driven team design project. Topics covered in the course included ethics and societal impact, as communicated primarily via guest lectures and an associated individual short written assignment. For ABET, instructors rated the ethics and societal impact learning objectives as emphasized to a medium extent in the course.

\section{CVEN 5525 Analysis of Framed Structures (Framed Structures)}

This course is a cross-listed course that enrolls 30-40 civil and architectural engineering seniors and first year graduate students focusing on structural engineering. At the end of the course, students are expected to be able to analyze statically indeterminate structures by hand and using computers, evaluate structural analysis results and develop simple structural analysis software. Course work includes weekly homework assignments, exams, and a programming project. Students are introduced through lecture and in class problems to a wide variety of contemporary and historical structures as it relates to unique analysis and design challenges, including sustainability issues.

\section{CVEN 5919 Sustainable Community Development I (SCD I)}

Enrollment in SCD1 is restricted to students pursuing a special graduate certificate program in Engineering for Developing Communities. Thus, there is likely a self-selection that students with higher social responsibility enroll into the course. For example, many of the students have worked on service projects in the past, such as via EWB or the Peace Corps, and hope to return to such projects in their careers. The students come from any discipline within civil engineering, but largely environmental, civil systems, structures, and construction management. The learning in the course centers on team-based projects for a real community.

At the end of each semester, students are asked to fill out Faculty Course Questionnaires (FCQs) for each course in which they were enrolled. In addition to overall course and instructor ratings, the undergraduate CVEN and EVEN courses ask students to rate the extent to which the program learning outcomes (which closely map to the ABET A-K criteria) were improved by the course. The average scores for students' self-reported improvement of understanding of ABET criteria F and $\mathrm{H}$ from previous years are given in Table 3 (Note: Updated FCQ data from the exact courses surveyed will be available in February, 2012). Students were asked to rate improvement on a Likert-style scale from 0-6. The FCQ ratings in ethics and understanding societal impacts aided in the selection of courses that formed the basis for this study.

Table 3. Course FCQ Average Scores for ABET Outcomes F \& H

\begin{tabular}{|l|c|c|}
\hline \multirow{2}{*}{ Course } & \multicolumn{2}{|c|}{ Average FCQ Scores } \\
\cline { 2 - 3 } & $\begin{array}{l}\text { Understanding of ethics and } \\
\text { professional responsibility }\end{array}$ & $\begin{array}{l}\text { Understanding of the impact } \\
\text { of engineering on society }\end{array}$ \\
\hline All CVEN Courses & 3.30 & 4.00 \\
\hline Intro to EVEN & 4.80 & 4.32 \\
\hline Intro to $C V E N$ & 4.95 & 4.95 \\
\hline Fund. EVEN & 4.00 & 4.70 \\
\hline Sr. Design & 4.70 & 5.10 \\
\hline
\end{tabular}




\section{Sample Population}

Paper and electronic survey distribution was used for the pre- survey given within the first two weeks of the semester, and only paper distribution was used for the post- survey given in the last two weeks of the semester. For all paper surveys, students were given time in class to complete the survey, but electronic surveys were to be completed outside of class. In total, 435 students responded to the pre- survey, 229 students responded to the post- survey, and 188 students responded to both the pre- and the post- survey. The demographic information of the respondents is summarized in Table 4 . The pre- and post- response rates for each course are given in Table 5.

Table 4. Fall 2011 Sample Population Demographics

\begin{tabular}{|l|l|c|c|c|}
\hline \multicolumn{2}{|l|}{ Category } & Pre- Total & Post- Total & Pre- and Post- \\
\hline TOTAL number of respondents & 435 & 229 & 188 \\
\hline & & & & \\
\hline Gender & Male & 280 & 145 & 121 \\
\hline & Female & 117 & 70 & 62 \\
\hline & & & & \\
\hline Academic Rank & Freshman & $228^{*}$ & 76 & 62 \\
\hline & Sophomore & 62 & 27 & 24 \\
\hline & Junior & 41 & 48 & 35 \\
\hline & Senior & 47 & 40 & 27 \\
\hline & Graduate & & & 38 \\
\hline Major & & 169 & 138 & 111 \\
\hline & Civil Engineering & 41 & 54 & 41 \\
\hline & Environmental & & & 7 \\
\hline & Engineering & $50^{*}$ & 7 & 29 \\
\hline & Mechanical Engineering & $176^{*}$ & 30 & \\
\hline
\end{tabular}

* Note that the survey was distributed electronically to all introductory engineering freshman courses for the pre- only and their intended major was asked, increasing the diversity of majors represented.

Table 5. Response Rates for Each Pilot Study Course

\begin{tabular}{|l|c|c|c|c|}
\hline Course & $\begin{array}{l}\text { Total course } \\
\text { enrollment }\end{array}$ & $\begin{array}{l}\text { Total respondents to both } \\
\text { pre- and post- survey }\end{array}$ & \% response rate & $\begin{array}{l}\text { \% female } \\
\text { respondents }\end{array}$ \\
\hline Intro to EVEN & 69 & 28 & 41 & 64 \\
\hline Engr. Projects & 31 & 17 & 55 & 29 \\
\hline Intro to CVEN & 48 & 34 & 71 & 21 \\
\hline Fund. EVEN & 81 & 49 & 60 & 29 \\
\hline Sr. Design & 79 & 15 & 19 & 13 \\
\hline Framed Structures & 33 & 23 & 70 & 22 \\
\hline SCD I & 27 & 22 & 81 & 50 \\
\hline
\end{tabular}




\section{Results/Discussion}

Research Question \#1: Are there differences among the attitudes of incoming engineering students who have identified different majors of primary interest?

In recent years, recruitment tactics geared towards prospective engineering students have focused on themes of making a difference in the world, making the world a better place, and following one's dreams. With this framework as the way in which the college advertises itself to incoming students, it is important to examine student perspectives as incoming freshmen. Using results from the EPRA responses of all freshman pre-surveys, average scores for each construct were determined. These scores capture the views of students as they enter into the engineering field within the first two weeks of starting college. Average scores are compared based upon the intended major of each student and are shown in Figure 1.

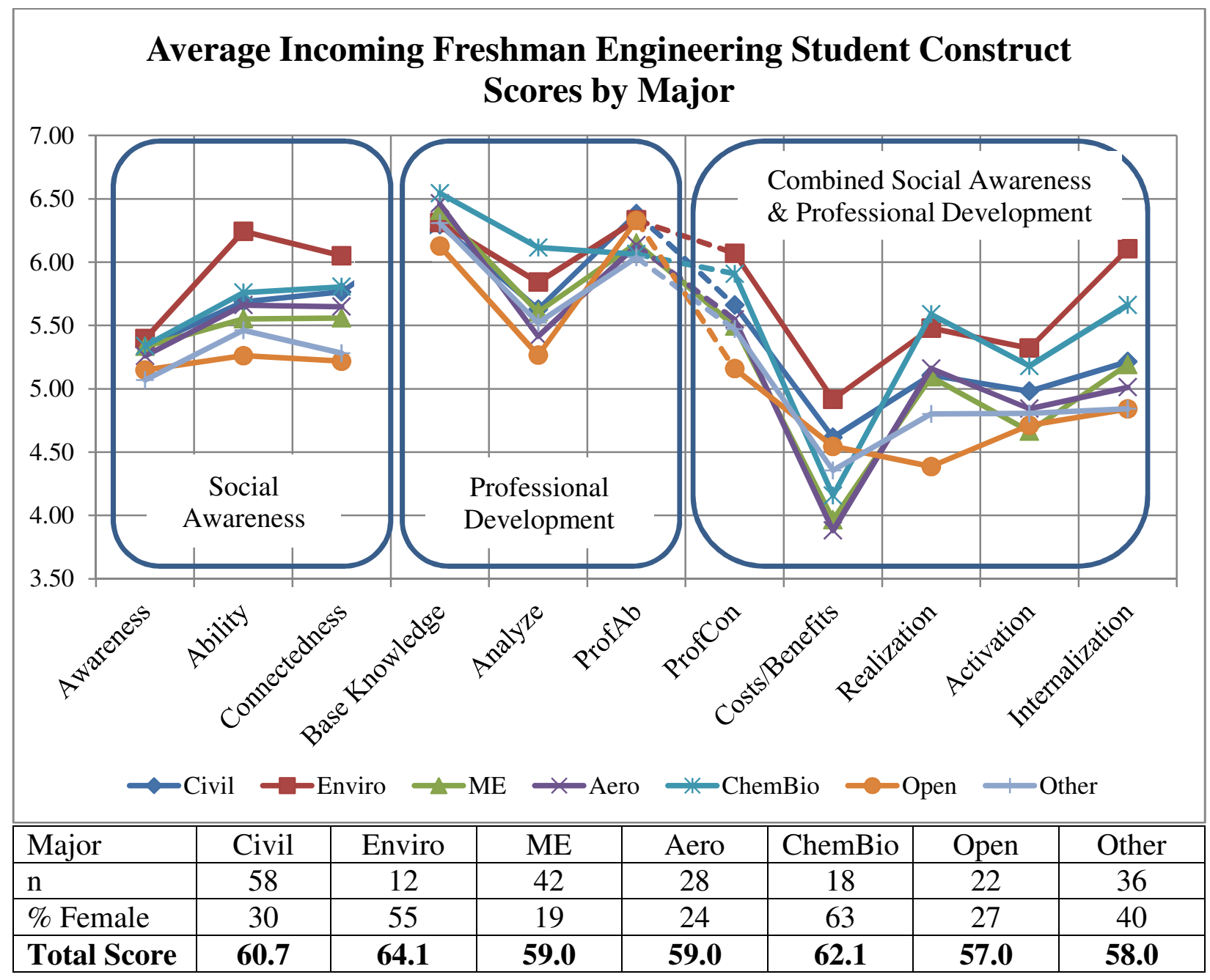

Figure 1. Scores of Freshman Engineering Students by Major

Of the incoming freshman engineering students surveyed, Environmental and ChemicalBiological Engineering students reported higher total scores than other majors assessed. 
Environmental Engineering Freshman reported higher averages on most constructs than other majors, most notably Ability and Internalization. Chemical-Biological Engineering students showed higher averages on the Analyze Construct, suggesting a stronger ability to analyze social problems from a professional perspective. It is worth noting that these majors also had higher percentages of female respondents, which may be a confounding factor in the higher averages.

Incoming engineering student with undeclared majors (Open) responded consistently lower construct averages than students who already had intent to pursue a specific engineering discipline. Perhaps the lower scores on an engineering specific assessment tool such as EPRA could be from having less of an identity associated with engineering at that point.

One of the short answer questions on the pre-survey asked student to describe their ideal engineering career, discussing types of projects, clients, locations, etc. Student responses were coded on a 3 point scale. Responses with scores of 2 or 3 included descriptions of working conditions that considered client involvement or team work, environmental health, sustainability, service, developing countries, or some form of helping language such as "improve quality of life". Responses with a score of 1 contained purely technical responses that seemed to occur in a vacuum, devoid of any acknowledgements of external factors, clients, or social impacts.

The results from the incoming freshman pre-surveys, by major, are presented in Figure 2 . The distribution of Civil and Mechanical Engineering students is about the same, with about $60 \%$ of respondents with scores of 2 or 3. In Environmental Engineering, 75\% of respondents had scores of 2 or 3 . In Aerospace Engineering, a significant portion of the responses (81\%) were purely technical in nature, neglecting to mention benefits to society or community participation in any form.

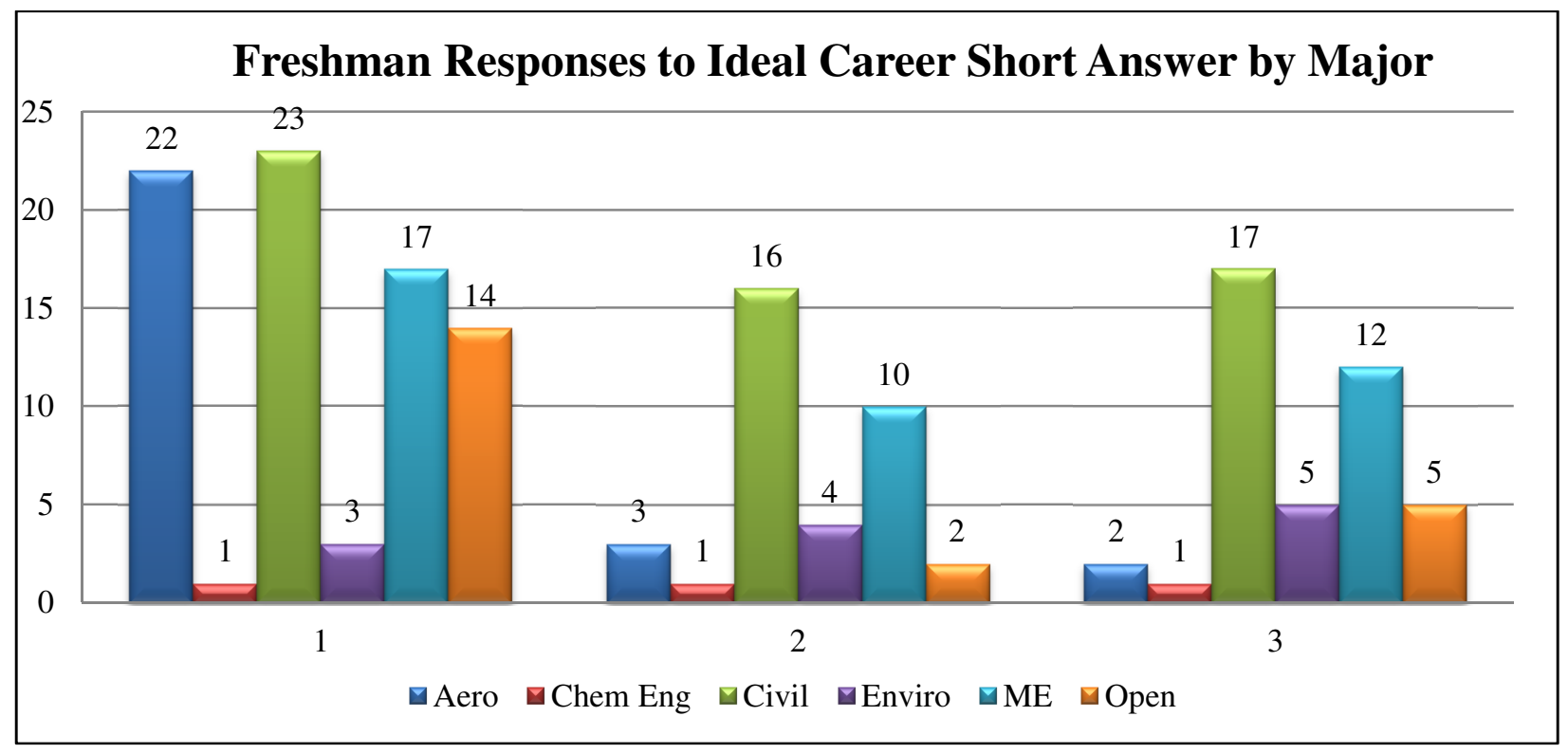

Figure 2. Freshman Responses to Ideal Career Short Answer by Major 


\section{Summary of Pre-Post Results}

In order to address research questions 2-4, the average responses for each construct and each course were calculated for respondents who completed both the pre- and post- surveys. The numbers of students from each course who completed both the pre- and post- surveys are shown in Table 5. In addition to average pre- and post- scores, the average difference between individual's pre- and post- responses was calculated. A two-tailed, paired t-test was used to determine if there was a statistically significant difference in the pre- and post- scores of the individual students, with a p-value less than 0.05 designating substantial significance $[\Delta$ cells in black] and $\mathrm{p}<0.1$ designating fair statistical significance [ $\Delta$ cells in gray]. Total scores for each course are also calculated as the sum of the construct averages to provide a high level view of the responses from a given group. All of these numbers are given in Table 6.

\section{Table 6. Fall 2011 Pre-Post Results}

\begin{tabular}{|c|c|c|c|c|c|c|c|c|c|c|c|c|c|}
\hline \multirow[b]{2}{*}{ Class } & \multirow[b]{2}{*}{ Measure } & \multicolumn{11}{|c|}{ Constructs } & \multirow[b]{2}{*}{$\stackrel{\bar{J}}{\stackrel{\tilde{\theta}}{\theta}}$} \\
\hline & & 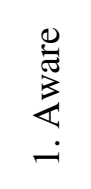 & 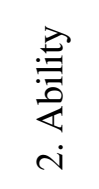 & $\begin{array}{l}\tilde{\Xi} \\
\dot{0} \\
\dot{\theta}\end{array}$ & $\begin{array}{l}0 \\
0 \\
\tilde{\Xi} \\
\oplus \\
\dot{\nabla}\end{array}$ & 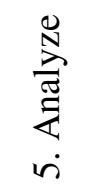 & $\begin{array}{l}0 \\
\mathbb{1} \\
0 \\
0 \\
0\end{array}$ & 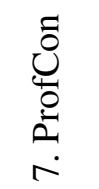 & $\underset{\infty}{\mathscr{\infty}}$ & 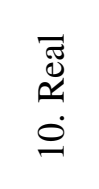 & 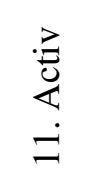 & $\begin{array}{l}\vec{\Xi} \\
\stackrel{\Xi}{ }\end{array}$ & \\
\hline \multirow{3}{*}{$\begin{array}{l}\text { Intro to } \\
\text { EVEN } \\
(\mathrm{n}=28)\end{array}$} & & & & 586 & 6.46 & & & & (1) & .47 & 5.14 & 5.78 & 68.7 \\
\hline & Avg. Post & 6.41 & 5.91 & 5.84 & 6.25 & 5.97 & 6.44 & 6.02 & 5.25 & 5.56 & 5.08 & 5.08 & 68.4 \\
\hline & & 0.48 & & 0.06 & -0.22 & -0.05 & 0.21 & -0.11 & 0.07 & 0.07 & -0.05 & -0.12 & \\
\hline \multirow{3}{*}{$\begin{array}{l}\text { Engr. } \\
\text { Projects } \\
(n=17)\end{array}$} & Avg. Pre & 6.18 & 5.12 & 5.28 & 6.19 & 5.17 & 6.38 & .42 & 5.18 & 4.60 & 4.67 & 4.80 & 63.5 \\
\hline & Avg. Post & 6.03 & 5.50 & 5.20 & 6.45 & 5.68 & 6.38 & 5.54 & 5.41 & 4.90 & 4.71 & 4.71 & 65.0 \\
\hline & Avg. $\Delta$ & .15 & 0.38 & -0.07 & 0.27 & 0.51 & -0.01 & & 0.24 & 0.31 & 0.05 & 0.18 & \\
\hline \multirow{3}{*}{$\begin{array}{l}\text { Intro to } \\
\text { CVEN } \\
(\mathrm{n}=34)\end{array}$} & Avg. Pre & 6.47 & 5.76 & 5.79 & 6.23 & 5.53 & 6.47 & 69 & 5.18 & 5.08 & 5.12 & 5.29 & 67.5 \\
\hline & Avg. Post & & 5.96 & 5.75 & 6.09 & 5.55 & 6.31 & 5. & 5.44 & 5.26 & 5.12 & 5.12 & \\
\hline & & .01 & 0.20 & -0.04 & -0.14 & 0.02 & -0.16 & 0.09 & 0.26 & 0.20 & 0.00 & 0.24 & \\
\hline \multirow{3}{*}{$\begin{array}{l}\text { Fund. } \\
\text { EVEN } \\
(\mathrm{n}=49)\end{array}$} & g. Pre & & 5.46 & 5.52 & 6.01 & 5.52 & 6.37 & & 5.05 & 4.87 & 4.97 & 5.30 & 65.1 \\
\hline & g. Post & & 5.36 & 5.35 & 5.98 & 5.44 & 6.17 & 5.49 & 5.01 & 4.73 & 4.95 & 4.95 & 63.8 \\
\hline & Avg. $\Delta$ & -0.01 & -0.06 & -0.14 & -0.03 & -0.06 & -0.20 & -0.13 & -0.04 & -0.14 & -0.02 & -0.11 & \\
\hline \multirow{3}{*}{$\begin{array}{l}\text { Sr. } \\
\text { Design } \\
(\mathrm{n}=15)\end{array}$} & Avg. Pre & 6.07 & 5.65 & 5.67 & 6.08 & 5.41 & 6.02 & 5.65 & 5.10 & 4.50 & 5.05 & 5.35 & נידנס \\
\hline & Avg. Post & 6.33 & 5.73 & 5.57 & 6.06 & 5.33 & 6.42 & 5.59 & 5.33 & 5.02 & 4.97 & 4.97 & 65.6 \\
\hline & Avg. $\Delta$ & 0.21 & 0.08 & -0.06 & -0.02 & -0.07 & 0.41 & -0.06 & 0.23 & 0.44 & -0.07 & 0.21 & \\
\hline \multirow{3}{*}{$\begin{array}{l}\text { Framed } \\
\text { Struct. } \\
(\mathrm{n}=23)\end{array}$} & Avg. Pre & & 5.25 & 5.10 & 5.97 & 4.95 & 6.17 & 5.27 & 4.93 & 4.50 & 4.79 & 4.68 & 01.0 \\
\hline & Avg. Post & 5.89 & 5.15 & 5.02 & 5.93 & 4.98 & 5.80 & 5.19 & 4.83 & 4.70 & 4.85 & 4.85 & 61.4 \\
\hline & Avg. $\Delta$ & -0.04 & -0.10 & -0.09 & -0.04 & 0.02 & -0.37 & -0.08 & -0.11 & 0.20 & 0.05 & 0.08 & \\
\hline \multirow{3}{*}{$\begin{array}{l}\text { SCD I } \\
(\mathrm{n}=22)\end{array}$} & Avg. Pre & 6.45 & 6.09 & 6.15 & 5.72 & 5.45 & 6.18 & 5.97 & 4.14 & 5.43 & 5.70 & 6.16 & 68.4 \\
\hline & Avg. Post & 6.41 & 5.95 & 5.98 & 5.73 & 5.80 & 5.94 & 5.89 & 4.93 & 5.40 & 5.79 & 5.79 & 68.6 \\
\hline & Avg. $\Delta$ & -0.11 & -0.14 & -0.17 & 0.02 & 0.34 & -0.24 & -0.08 & 0.8 & -0.03 & 0.09 & -0.35 & \\
\hline
\end{tabular}

Black designates $\mathrm{p}<0.05$

Grey designates $\mathrm{p}<0.10$

In general, the average pre- values shows high saturation $(>6.0)$ from most courses for constructs 1 (Awareness), 4 (Base Knowledge) and 6 (Professional Ability). This high saturation in the pre- survey, led to a negative change for many of the post- survey results. The negative change 
in base knowledge for Intro to CVEN and Intro to EVEN for construct 4 is probably a recalibration of relative importance of skills as the first-year students gained a better understanding of what engineering is in their first semester. The post values for these classes are more in line with the post values from other, higher level courses, suggesting an understanding that comes with more exposure to the field. Additionally, four of the seven courses had significantly negative change for construct 6 (Professional Ability), which could also be explained by the high initial averages.

To assess Construct 9 (Action), students were asked on the pre-survey to mark how frequently they had volunteered with different organization or activities since starting college. Student responses were scored based upon a double weighting system where different volunteer activities and frequency of involvement were weighted. Table 7 summarizes the double weighting system. In this pilot study, the student scores ranged from 0 to 440, with an overall median score of 10. Volunteer frequency scores, as a percentage of total responses from each course, are shown in Figure 3 for all pre-survey respondents. Contrary to expectations, the volunteer frequency scores did not correlate to participant total Likert scores as seen in Figure 4.

Table 7. Volunteer Frequency Score Double Weighting System

\begin{tabular}{|l|c|}
\hline Volunteer Activity & Weight \\
\hline Donating Blood, In-class Service Learning Project & 1 \\
\hline $\begin{array}{l}\text { Food Bank, Meals on Wheels, Nursing Home, Political Campaign, Big } \\
\text { Brother/Big Sister, Boy \& Girl Scouts, Boys/Girls Club, Soup Kitchen, } \\
\text { Unpaid Tutoring (elementary, secondary, or college) }\end{array}$ & 2 \\
\hline EWB Project & 3 \\
\hline Habitat for Humanity Build & 5 \\
\hline Disaster Relief or International Humanitarian Volunteer & 10 \\
\hline Frequency & 1 \\
\hline Once & 2 \\
\hline Twice & 5 \\
\hline More than Twice but not routinely & 20 \\
\hline Monthly & 50 \\
\hline Weekly & \\
\hline
\end{tabular}




\section{Double Weighted Volunteering Score by Course}

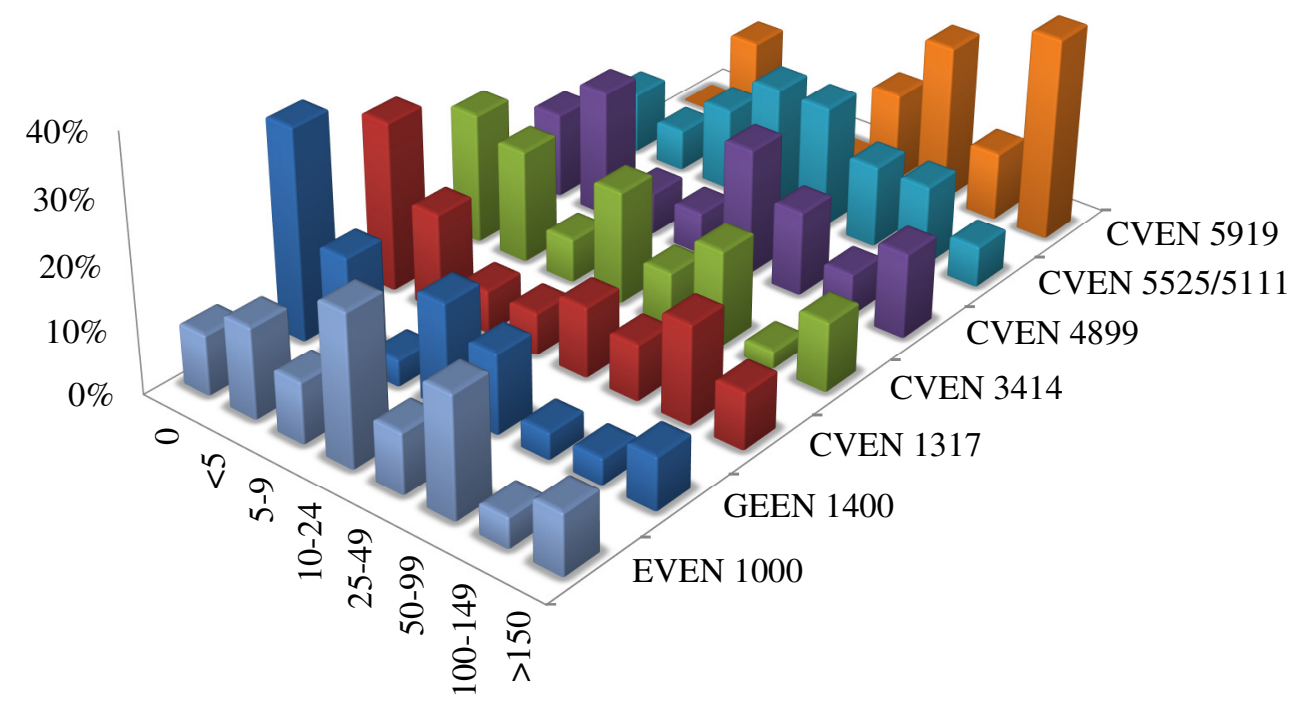

Figure 3. Double Weighted Volunteering Score by Course

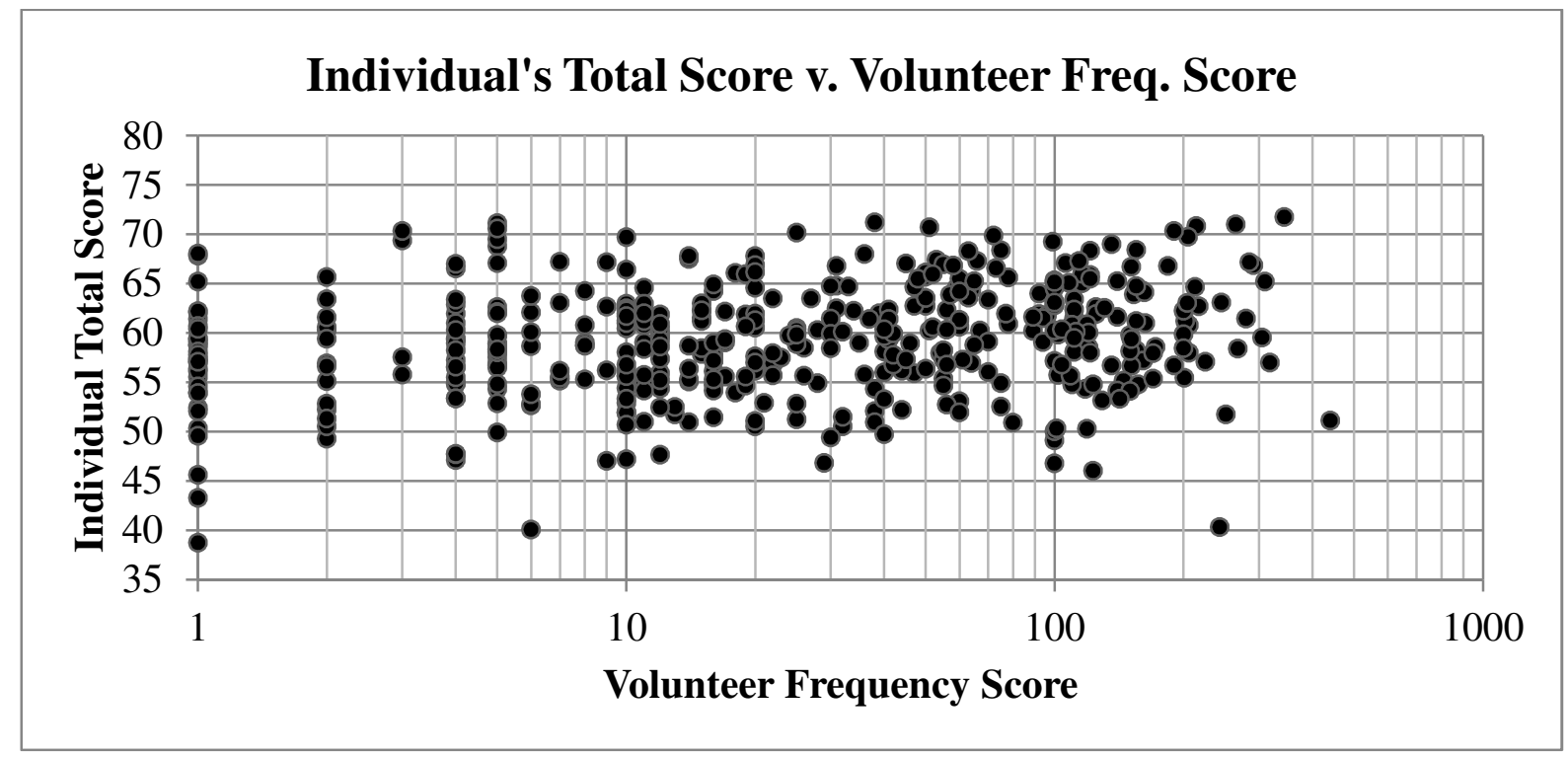

Figure 4. Individual's Total Score vs. Volunteer Frequency Score

Course Specific Post- Questions

On the post-survey, students were asked to rate how much the specific course surveyed contributed to ABET F and $\mathrm{H}$ skills, as well as general skills related to working with clients and balancing community needs (skills associated with LTS). A three-point Likert-style scale was 
used, with 1 as "Did Not Contribute", 2 as "Contributed Slightly", and 3 as "Contributed Significantly." The average ratings for all respondents to the post-survey, by course, are shown in Figure 5

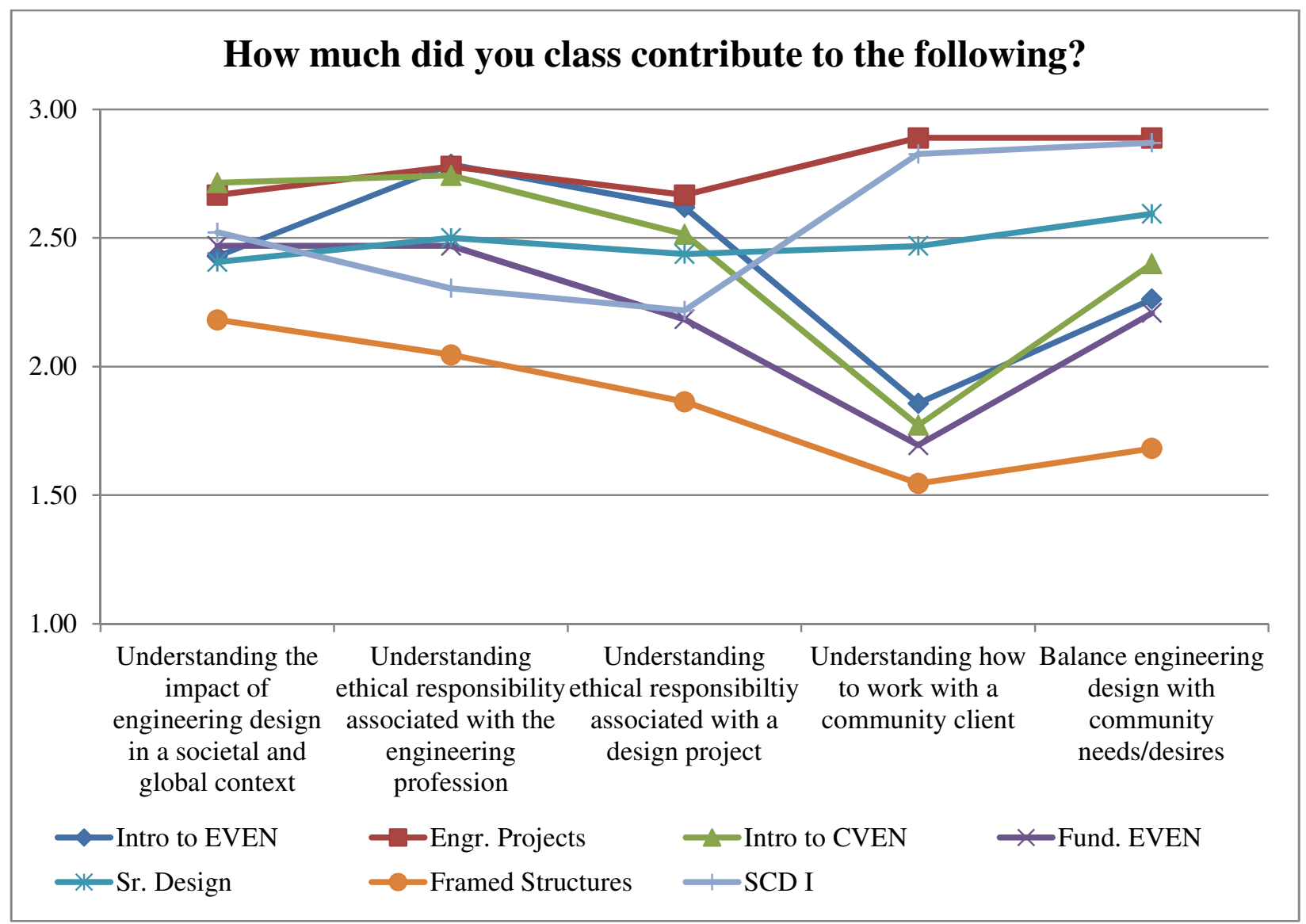

Figure 5. Average Rating for Course Contribution to Professional Skills

The pre-post survey results will be used in the following sections to more directly address research questions 2,3 and 4 .

\section{Research Questions \#2 \& \#3: ABET F \& H, and Teaching Method}

From Table 2 we see that Intro to EVEN and Intro to CVEN are the only courses assessed that have ABET outcome F as a central learning objective. The total scores shown in Table 6 suggest that there was little change in overall understanding of social responsibility over the course of that semester. Examination of the changes at the construct level show statistically significant increases in attitudes for Constructs 1 (Awareness) and 6 (Professional Ability) for Intro to $E V E N$, and increases for Constructs 2 (Ability) and 12 (Internalization) for Intro to CVEN. Both courses showed statistically significant decreases in Construct 4 (Base Knowledge), but as stated before, this is most likely attributed to the naivety of incoming freshman on the relative importance of technical and professional skills for engineers. There did not seem to be, however, any pattern from the Likert questions that uniquely bound these two courses together or separated them from courses where ABET F was not a central learning objective. For example, 
where Intro to EVEN had significant increase in Construct 1 (Awareness), Intro to CVEN had no change and for Construct 6 (Professional Ability), Intro to EVEN students showed a significant increase while Intro to CVEN students showed a significant decrease.

When students were asked directly about the effect of that particular course to their understanding of ethical responsibility (ABET F), students from both Intro to EVEN and Intro to $C V E N$ answered significantly $(\mathrm{p}<0.05)$ higher than most other courses on questions 2 and 3 , as seen in Figure 5. This may support the idea that while student's recognized that ethics was an important aspect of their course, it did not affect attitudes more generally on social responsibility. One other explanation is that the Likert-style questions may not accurately capture the nature of professional ethics in the style that it is taught in standard courses.

To examine if a focus on ABET outcome $\mathrm{H}$ affects attitudes of social responsibility, Sr. Design and SCD I were compared to other courses. At this point, it should also be noted that both of these courses employ PBL/PBSL as a teaching method, which may be a confounding factor. $S r$. Design showed a significant increase in Construct 6 (Professional Ability) compared to most other courses where there was a significant decrease. Construct 6 focuses on the recognition of one's professional abilities to help those in need, and so it is expected that a course which focuses on ABET H should increase scores for Construct 6.

Scores for $S C D$ I were highly saturated in the pre-survey and total scores remained high in the post-survey, and being a graduate level program of student interested in development work, this result is not too surprising. A number of scores did decrease for this class, which may be due to a greater exposure to the reality of engineering development work and the difficulty of making significant, lasting and sustainable change. Both courses had high ratings in the post-survey question specifically addressing the impacts of engineering on society (Figure 5, Question 1), but were not very different from other courses.

To examine the effects of different teaching methods, specifically PBL and PBSL versus traditional methods, Engr. Projects, Sr. Design, and SCD I were courses that use PBL and PBSL as a dominant component. The results from Sr. Design and SCD I discussed above probably relate more to the use of PBL/PBSL than ABET H (thought the two are related) as demonstrated by the higher responses to questions 4 and 5 in Figure 5 along with Engr. Projects. As the common factor between these three classes, it would seem that the use of PBL and PBSL was, predictably, a controlling factor in responses to questions 4 and 5.

Engr. Projects, which focuses heavily on PBSL with community partners, showed the most significant increase in student recognition of their ability to solve social problems (Construct 2), ratings of the importance of base technical and professional skills (Construct 4), and the ability to use analyze social issues using professional skills (Construct 5). When asked to describe any events in this course that affected their views of community service and social responsibility, two students from Engr. Projects said that following, supporting the increases in constructs 2, 4 and 5:

"Having a client in GEEN 1400 (Engr. Projects) has opened my eyes to how engineering helps people", 
and

"Daily engineering videos have shown me that engineers have problem solving skills that can greatly help society; therefore we have some responsibility."

The exposure to PBSL for these incoming freshman seemed to have a large effect on the Engr. Projects students' attitudes of social responsibility, evidenced also in that Engr. Projects had the largest increase in total scores: pre- to post-.

Pursuant to the framework and introduction of this study, involvement in EWB was also examined as another form of LTS engagement that could affect student's beliefs of social responsibility. The construct averages for students who engaged in EWB more than twice or on a regular basis (monthly or weekly) are compared to construct average scores for students who did not report volunteering with EWB more than twice, and these scores are shown in Figure 6. All responses to the pre- survey were used for this examination. Two-sample unequal variance ttesting showed that the students who engaged in EWB activities had statistically significant higher scores $(\mathrm{p}<0.05)$ for the following constructs: Ability, Connectedness, Professional Connectedness, Activation and Internalization. These results may suggest that involvement in EWB, similar to PBL/PBSL in the classroom, aid in students' understanding of social responsibility, most importantly in areas of moral obligation (Connectedness and Professional Connectedness) and areas of deeper personal identification and association with social issues (Activation and Internalization).

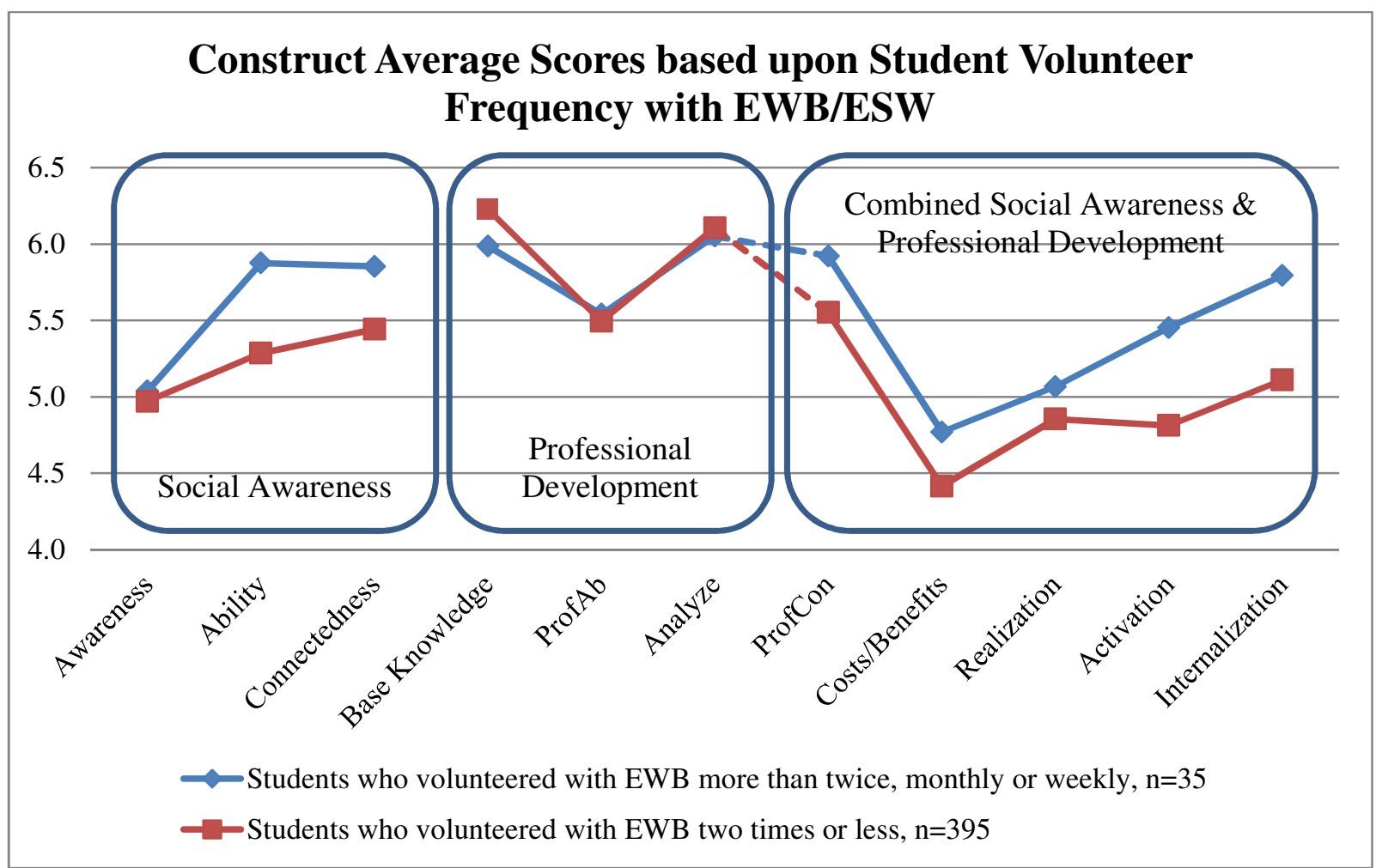

Figure 6. Construct Average Scores for Students based upon volunteer frequency in EWB 
Research Question \#4: Does social responsibility tend to change over time through a civil engineering curricula?

One item of interest in this research is to see how student attitudes of social responsibility change over the course of an undergraduate career. Since longitudinal studies of this fashion are difficult, for this project cut-points across different academic years are taken and examined. The pre- and post- averages for Intro to CVEN, Fund. EVEN, and Sr. Design sample all four academic years within a civil engineering program. Additionally, Framed Structures and SCD I give evidence for two separate graduate civil engineering tracks, one more traditional and the other related to development work using engineering.

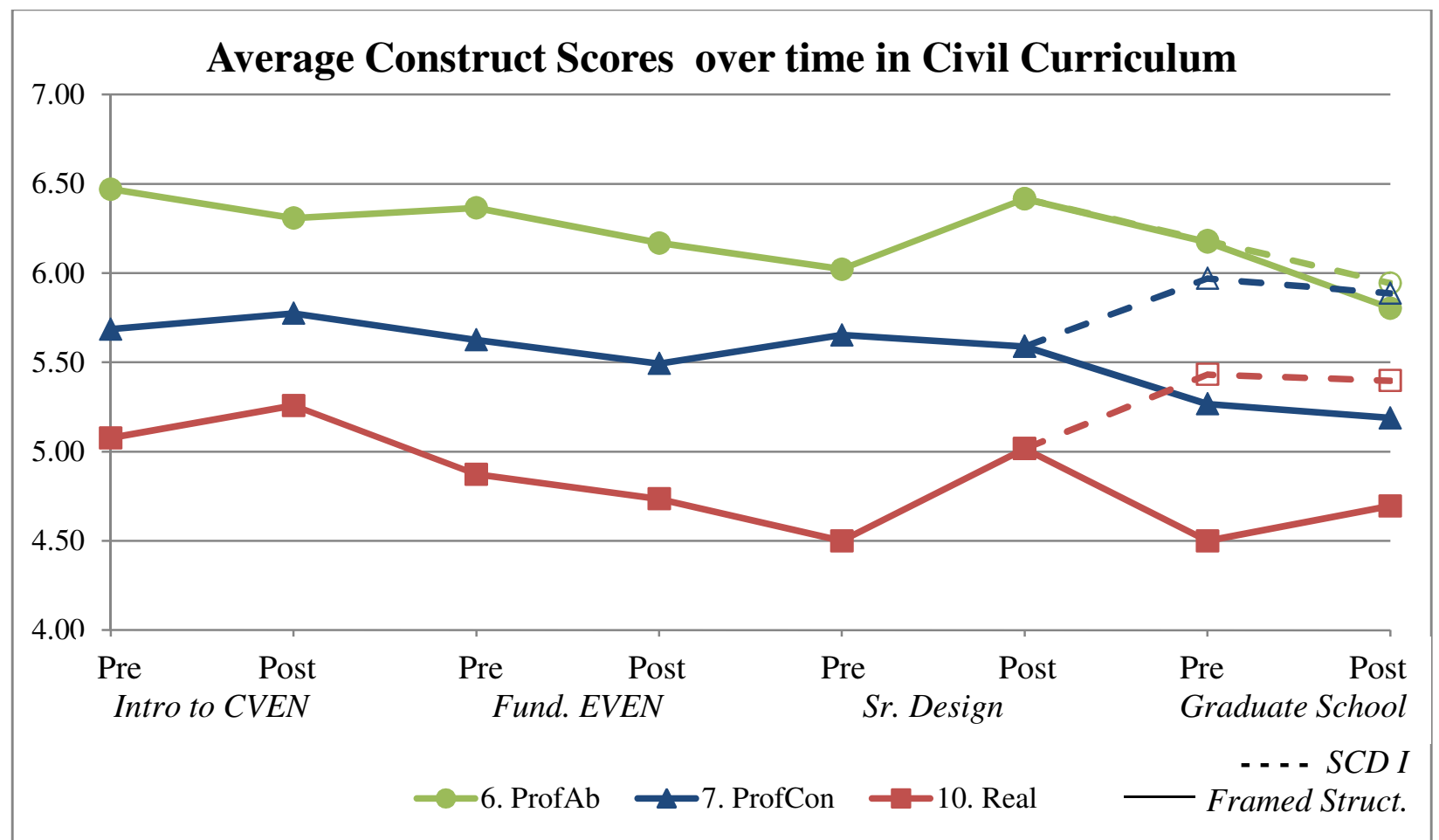

\section{Figure 7. Average Construct Scores for Cut-point Classes in Civil Curriculum}

Figure 7 shows the average scores for the pre- and post- surveys of these courses, providing a snapshot of attitudes of social responsibility through and undergraduate and graduate career. Constructs 6 (Professional Ability), 7 (Professional Connectedness) and 10 (Realization) were chosen because they represent the development of professional social responsibility most directly and gauge the way in which a student's formal academic training influences their attitudes of social responsibility.

In general, all constructs trend downward over the four years of undergraduate education and through the traditional civil engineering graduate program as well. It is always worth noting the rise in 6 and 10 at the end of the Senior Capstone project, presumably helping engineering students to see the bigger picture and gain a better understanding of the application of their engineering knowledge. The difference between the SCD I and Framed Structures graduate students is also interesting. Assuming that both sets of graduate students had similar undergraduate training, the split off of the Sr. Design course would be an accurate division of 
student pursuing these two paths in graduate school. Except for Construct 6, the SCD I student showed significant increases in 7 and 10 over the traditional Framed Structures students.

Finally, Constructs 6 and 10 demonstrate clearly a steady decline over the Sophomore and Junior years, where courses tend to be traditional lecture courses with a heavy technical focus. This supports the idea that gauging incoming freshman at the end of the first semester, to allow for accurate calibration of knowledge, and the beginning and end of senior year may provide an accurate picture of the general student's entire undergraduate experience.

\section{Summary and Conclusions}

In summary, the pilot study conducted using the EPRA tool to gauge engineering students' attitudes towards personal and professional social responsibility was successful and provided interesting data for analysis. It was found that incoming Environmental and ChemicalBiological Engineering students reported higher scores over most constructs, but these samples also had a higher percentage of female respondents which may be a confounding factor. Further research on the breakdown by gender will be conducted. Examining courses which placed heavy emphasis of ABET $\mathrm{F}$ and $\mathrm{H}$ as learning objectives showed little change over the course of the semester, however the use of LTS alternative teaching methods such as PBL and PBSL seem to increase students ABET H performance and knowledge of working with clients. Additionally, students who engaged in volunteer activities with EWB reported higher averages for feelings of moral obligation to help others and higher personal association with social issues. Finally, when courses over all academic years were considered as cut-points through the Civil Engineering curriculum, it was seen that attitudes of social responsibility steadily decrease from the Freshman post- surveys to the Senior Pre- surveys, but the exposure to a senior design capstone project seemed to increase most scores back near the original pre-survey freshmen levels. The diversity of graduate programs between a traditional path and the sustainable community development program was clearly evident in the higher scores of the latter, as well.

Further studies are underway to better improve the EPRA tool and to further assess the development of students' attitudes of social responsibility. It would be surprising for dramatic changes in beliefs to occur over one semester, so longer range studies will be attempted to see if over the course of a year, students are more likely to show differences. Additionally, a wider range of courses, majors and academic years will be surveyed over five institutions to assess differences among universities, programs, degrees and students. Interviews will be conducted to examine the accuracy of the EPRA tool at capturing the nuances in behavior and belief development in engineering students as well. Finally, post-collegiate experiences of students showing high levels of social responsibility will be examined to further understand the "downstream" effects of developing personal and professional social responsibility in engineering students. 


\section{Bibliography}

1. ABET, "Criteria for Accrediting Engineering Programs Effective for Evaluation During the 20092010 Accredidation Cycle," ABET Engineering Accreditation Commission, 2008.

2. Entrepreneur, "Entrepreneur Encyclopedia: Social Responsibility," 2011. [Online]. Available: http://www.entrepreneur.com/encyclopedia/term/82646.html. [Accessed 21 July 2011].

3. A. Carberry, "National Engineering Students' Learning Outcomes Survey (NESLOS)," Tufts University, 2010.

4. A. R. Carberry, "Characterizing Learning-Through-Service Students in Engineering by Gender and Academic Year," Tufts University, 2010.

5. A. Bielefeldt, K. Paterson and C. Swan, "Measuring the Impacts of Project-Based Service Learning," in American Society for Engineering Education Conference and Exposiion Proceedings, Austin, 2009.

6. W. Oakes, "Creating Effective and Efficient Learning Experiences while Addressing the Needs of the Poor: An Overview of Service-Learning in Engineering Education," in Amercian Society for Engineering Education (ASEE) Conference and Exposition Proceedings, Austin, 2009.

7. J. Ejiwale and D. Posey, "Enhancing Leadership Skills through Service Learning," in American Society for Engineering Education Conference and Exposition Proceedings, Pittsburgh, 2008.

8. A. Bielefeldt, "Increasing International Awareness of Engineering Students," in American Society for Engineering Education Conference and Exposition Proceedings, Chicago, 2006.

9. A. W. Astin, L. J. Vogelgesang, E. K. Ikeda and J. A. Yee, How Service Learning Affects Students, Los Angeles: Higher Education Research Institute, 2000.

10. J. J. Duffy, L. Barrington and M. A. Heredia Munoz, "Attitudes of Engineering Students from Underrepresented Groups Toward Service-Learning," in Proceedings of the Annual ASEE Conference and Exposition, Vancouver, BC, 2011.

11. N. Canney and A. Bielefeldt, "A Model for the Development of Personal and Professional Social Responsibility for Engineers," in Proceedings of the Annual ASEE Conference and Exposition, San Antonio, TX, 2012.

12. S. H. Schwartz and J. A. Howard, "Helping and Cooperation: A Self-Based Motivational Model," in Cooperation and Helping Behavior: Theories and Research, New York, Academic Press, Inc., 1982, pp. 327-353.

13. S. Schwartz, "Normative influences on altruism," Advances in experimental social psychology, vol. 
10, pp. 221-279, 1977.

14. J. Ramsey, "The Science Education Reform Movement: Implications for Social Responsibility"," Science Education, vol. 77, no. 5, pp. 235-258, 1993.

15. C. L. Delve, S. D. Mintz and G. M. Stewart, "Promoting values development through community service: A design," New Directions for Student Service, pp. 7-29, 1990.

16. A. H. Shiarella, A. M. McCarthy and M. L. Tucker, "Development and Construct Validity of Scores on the Community Service Attitudes Scale," Educational and Psychological Measurement, vol. 60, no. 2, pp. 286-300, 2000.

17. M. Besterfied-Sacre, C. J. Atman and L. J. Shuman, "Engineering Student Attitudes Assessment," Journal of Engineering Education, pp. 133-141, 2000.

18. C. J. Atman, S. D. Sheppard, J. Turns, R. S. Adams, L. N. Fleming, R. Stevens, R. A. Streveler, K. A. Smith, R. L. Miller, L. J. Leifer, K. Yasuhara and D. Lund, "Enabling Engineering Student Success: The Final Report for the Center for the Advancement of Engineering Education," Morgan \& Claypool Publishers, San Rafael, CA, 2010.

19. University of Colorado at Boulder, "Integrated Teaching \& Learning Program and Laboratory Courses and Workshops," Regents of the University of Colorado, 2012. [Online]. Available: http://itll.colorado.edu/index.php/courses_workshops/geen_1400/. [Accessed 6 January 2012]. 